\title{
Influences on Women's Choices of Careers in Construction: A South African study
}

Kolosa Madikizela, (Cape Peninsula University of Technology, South Africa)

Professor Theo Haupt, (Director Building and Construction Science, Mississippi State University, USA)

\begin{abstract}
This paper analyses the factors influencing the choices of careers in construction by South African women. The literature on challenges which influence women's choices of careers in construction was reviewed and questionnaires were conducted with multiple samples, including construction organisations, construction students and professional women working in construction. The study found that women have a role to play in the construction industry and that they can build successful careers within the sector. However, it was not easy given the various barriers to entry such as gender-based discrimination against them, the harsh work environment of the construction site, the lack of sufficient knowledge about the industry itself and the shortage of successful women in construction as role models. There was evidence of discrimination and sexual harassment. All these factors impacted negatively on the choices of careers in construction by South African women. This study makes a contribution to our understanding of the factors that have marginalised women in a male dominated industry and provides some indication of approaches to attract more women into the sector. It is hoped that it will stimulate debate about how the low representation of women in construction can be addressed and how construction careers for women can be promoted and encouraged and that the resource pool will be enlarged given the prevalent acute skills shortage in the industry.
\end{abstract}

Keywords: Sex discrimination, Education, Gender, Built environment, Career choices, Culture, Cultural background.

\section{Introduction}

Women encounter pervasive gender issues in their chosen careers which require specific strategies to deal with them (Phaahla, 2000). In particular, they need to contend with gender role stereotyping which is the belief that a set of traits and abilities is more likely to be found among one sex than the other (Schein, 1978). Women have been defined as inferior to men and therefore, they are assigned the position of minors in both public and private spheres of life (National Gender Policy Framework, 2003). Further, they arguably accept secondary roles without hesitation (Mathur-Helm, 2005). Although women constitute the major segment of the South African population they account for only $33.3 \%$ of the labour force. Gender inequality in the workplace is underpinned by job segregation and perceived roles associated with gender groups (Commission on Gender Equality, 1999). More specifically in the construction industry with the number of women presently low, the implication is that individuals, the industry, and ultimately the community all suffer the consequences of only fully utilizing the potential of one gender. Women are therefore, a wasted resource (MathurHelm, 2005). However prevailing attitudes suggest change will not be easy because the dominantly male makeup of the construction industry is a deterrent to women who fear isolation, discrimination and harassment should they pursue careers in that sector. The nature of the workplace culture in construction is critical in explaining the underachievement of women in construction careers. This culture militates against their equal progression through the somewhat exclusionary and discriminatory environment that characterises the sector. Women without an in-depth knowledge of the cultural influences on construction careers soon become disillusioned with the discrimination and the lack of opportunities for 
themselves. They are regarded by males as added competition for the limited promotional opportunities that exist and experience entrenched sexism (Bennett, Davidson and Gale, 1996). Consequently, attitudes of males are adversarial and confrontational. Further, many young men still believe women are both physically and psychologically unsuited to construction work, despite paying lip service to the notion that "women can do anything" (Thompson, 1996).

Typically young people start contemplating their career choices around the age of 16 or in their last years of high school. Gender-based career stereotyping makes it particularly difficult for young girls to establish their own career choices or to diverge from the career choices that their parents dictate. A sense of isolation is another reason for high defections with women having little chance of meeting other women working in construction. Education at school level is only part of the battle to recruit more women into the construction industry. Male builders need to accept women in the building workplace (Thompson, 1996).

There is a relationship between higher education and the employment choices of women (Phaahla, 2000). Women tend to congregate in areas seen as traditional outlets for female employment. Female staff and students are typically drawn to faculties such as the humanities, education and the social sciences. Generally women do not make up large numbers in technology and applied science areas of study. Consequently, the jobs available to women are limited due to social and economic reasons. The position of women is further exacerbated by the fact that gender in South Africa is also racially and culturally segmented, creating inequalities that are race-bound. White and Black women have extremely different levels of experiences regarding job and development opportunities (Mathur-Helm, 2005).

While more enlightened senior management staff may have recognised the undesirable and debilitating effects of an entrenched male culture, there was little evidence to suggest that there had been any significant erosion of it within the ranks of middle managers, employers or employees (Greed, 2006). Women are still regarded as secondary to men in South African business culture (Mathur-Helm, 2005). There is a view that women do not show leadership potential and behave differently from traditional male leaders (Mathur-Helm, 2004; Guppy and Rick, 1994). According to Johnson (1999) they are emotional and cannot shoulder responsibilities. What women do is rarely defined as leadership given that masculinity is an implicit construct of leadership (Kloot, 2004).

The South African definition of gender equality is guided by a vision of human rights which incorporates acceptance of the equal and inalienable rights of all men and women (Kornegay, 2000). Indeed, the rights of women need to be seen as human rights. In the Bill of Rights of the South African Constitution "equality" is specified and enshrined (The Republic of South Africa, 1996). Section 9(3) of the Constitution provides that no one may unfairly discriminate directly or indirectly against anyone on any grounds such as, for example, race, gender and culture. This prohibition on discrimination is an integral part of processes to achieve social justice in South Africa. Gender equality, therefore, requires that the underlying causes of discrimination are systematically identified and removed in order to give women and men equal opportunities in every sphere of life. According to the ILO:

In short, the economic integration of women, which comes only when market barriers are lowered and women are given an equal chance to attain decent work, remains a necessity for economic development and a worthy goal in its own right (2008:4).

In South African society women historically faced the burden of unpaid household labour in addition to income generating work. A rigid and uncompromising organisation of working hours and environment prevented them from performing well considering that they needed to take time off for childcare and other family responsibilities (Ellison, 2001 and Wilson, 1998). Often these demands reduced their chances of full-time paid employment. Furthermore in

Madikizela, K and Haupt, T (2010) 'Influences on women's choices of careers in construction: a South African study', Australasian Journal of Construction Economics and Building, 10 (1/2) 1-15 
terms of the South African Employment Equity Act of 1998, labour market discrimination arises when employers make decisions about employees for reasons that are not related to genuine work requirements (Republic of South Africa, 1998). Discrimination appears most obviously when an employer focuses on irrelevant personal characteristics instead of work performance or merit and women have to work extra well and hard to gain any prospect of promotion. Unfortunately women have not been benefitting from government policies and legislation to advance their careers (Mathur-Helm, 2005). There is, therefore, no correlation between policy and practice.

The generally accepted and popular image of construction is that of a male-dominated industry requiring brute strength and tolerance for outdoor conditions, inclement weather and bad language (Fielden et al., 1999). Women, therefore, have three choices, namely to be successful by behaving like men, fail to adapt to the culture and leave, or by not acting like men to remain in unimportant positions (Bennett, Davidson and Gale, 1996; Sachs, Chrisler and Devlin, 1992). According to Agapiou (2002), the image and perception of an industry were significant factors in determining career choice in their study. Furthermore the construction industry is perceived as being the epitome of crisis, conflict and masculinity manifesting in the unsociable, confrontational behaviour that discourages women and ethnic minorities from considering construction as a meaningful career. The industry had an industry-wide problem with 'image', which made both men and women reluctant or uninterested in the industry (Gale, 1994). Haupt and Smallwood, (2005) in their study found South African students had very limited knowledge and understanding of the construction industry. According to Fielden et al., (1999) the general lack of knowledge and information about the industry, the career opportunities it can offer and what qualifications are offered, further compound the problem of the low representation by women in the sector. Parents, teachers and school children generally believed that jobs in the construction industry were limited to bricklaying, joinery, painting and decorating.

Against the background that issues of gender equality have been extensively studied in advanced economies but less so in countries with less advanced economies, this paper highlights the findings of a study conducted in South Africa to examine the factors that influence the career choices of women with emphasis on the construction industry. The study examined the interconnection between gender, culture, religion, masculinity and the unattractive image of the construction industry and the career choices of women in South Africa. In particular, it provides insight into the popularity of careers in construction among women relative to other industrial sectors. It explores the prevalence of discrimination against women in construction and its overall impact on their final career choice preferences.

\section{Methodology}

A purposive sampling approach was adopted to gather data on the research topic. Construction companies, construction students, and professional women working in construction were surveyed using self administered questionnaires. Data was encoded and analysed using SPSS.

The views were canvassed of a convenience sample of 1,435 industry practitioners, 141 first and final year construction students and 17 professional women from the Gauteng and Western Cape provinces where arguably most construction activity in South Africa generally occurs. The industry survey included 11 questions on aspects of gender practices and policies within their organizations. The student and professional women survey instruments included 83 and 33 statements respectively to which respondents were required to respond typically using a 5-point Likert scale of agreement. 


\section{Industry Survey}

The industry sample was comprised of 1,435 participants in construction workshops held in all 9 provinces in South Africa over a 12 month period. The profile of the sample is shown in Table 1.

\begin{tabular}{|l|r|l|r|}
\hline \multicolumn{1}{|c|}{ Industry participation } & \multicolumn{1}{|c|}{ Province } & $\%$ \\
\hline Architect & 8.0 & Eastern Cape & 16.2 \\
\hline Contractor & 19.6 & Free State & 5.5 \\
\hline Engineer (consultant) & 21.3 & Gauteng & 15.7 \\
\hline Manufacturer & 1.5 & Kwazulu-Natal & 23.8 \\
\hline Private sector client & 5.8 & Limpopo & 3.5 \\
\hline Public sector client & 19.4 & Mpumalanga & 5.9 \\
\hline Project Manager (consultant) & 7.6 & Northern Cape & 4.0 \\
\hline Quantity Surveyor (consultant) & 7.0 & North West & 3.0 \\
\hline Co-contractor & 3.6 & Western Cape & 19.2 \\
\hline Supplier & 1.0 & Many provinces & 3.4 \\
\hline Other & 5.4 & Total & 100.0 \\
\hline Total & 100.0 & & \\
\hline \multicolumn{1}{|c|}{ Average annual turnover } & $\%$ & Average annual employment & $\%$ \\
\hline <R1million & 16.4 & $<10$ & 30.6 \\
\hline >R1million <R5million & 25.4 & $>11<50$ & 25.9 \\
\hline >R5million <R20million & 18.8 & $>50<100$ & 8.6 \\
\hline >R20million & 39.4 & $>100<250$ & 26.2 \\
\hline Total & 100.0 & $>250$ & 100.0 \\
\hline
\end{tabular}

Table 1 Industry sample profile

It is evident that the sample comprised mostly consulting engineers (21.3\%), contractors (19.6\%) and public sector clients (19.4\%) who operated mostly in Kwazulu-Natal (23.8\%), Western (19.2\%) and Eastern Cape (16.2\%) provinces of South Africa. Most participants had average annual turnovers greater than R5 million. Further, almost all (95.7\%) employed on average less than 50 workers per annum. From Table 2, it is evident that $90.5 \%$ of the sample employed less than 10 females on average per annum in their organisations. Table 3 confirms that women are mostly employed to perform secretarial (69.1\%) and administrative $(42.5 \%)$ roles. Where they were employed on construction sites they were mostly employed at the level of labourers (31.2\%).

\begin{tabular}{|l|c|}
\hline \multicolumn{1}{|c|}{ Number } & $\%$ \\
\hline$<10$ & 90.5 \\
\hline$>10<50$ & 5.2 \\
\hline$>50<100$ & 0.9 \\
\hline$>100$ & 3.4 \\
\hline Total & 100.0 \\
\hline
\end{tabular}

Table 2 Average annual employment of females

\begin{tabular}{|l|c|c|}
\hline \multicolumn{1}{|c|}{ Employment category } & \multicolumn{2}{c|}{$\%$} \\
\hline & Yes & No \\
\hline Secretarial & 69.1 & 30.9 \\
\hline Management (Administration) & 42.5 & 67.5 \\
\hline Unskilled (labourers) & 31.2 & 68.8 \\
\hline Skilled (artisans) & 19.9 & 80.1 \\
\hline Supervisory & 17.3 & 82.7 \\
\hline Semi-skilled (operators) & 16.2 & 83.8 \\
\hline
\end{tabular}

Table 3 Employment categories of females

Relative to being asked about the prevalence of certain gender-based issues and practices in their respective organisations almost all respondents reported that females were afforded 
the same rights, benefits and opportunities as males (92.2\%). Similarly, most of them reported that separate facilities such as toilets and ablutions were provided for females (83.2\%) and that females were afforded equal advancement and promotion opportunities (87.6\%). However, substantially less reported that funding was available targeted at improving the status and qualifications of female employees (51.1\%), written gender equity policies were in place (44.5\%), and gender-based educational material was provided to employees (27.8\%). Notably, a large proportion of almost $25 \%$ of respondents did not know what the situation was in their organisations relative to gender-related issues and practices.

\begin{tabular}{|l|c|c|c|}
\hline \multicolumn{1}{|c|}{ Issue } & $\begin{array}{c}\text { Yes } \\
\%\end{array}$ & $\begin{array}{c}\text { No } \\
\%\end{array}$ & $\begin{array}{c}\text { Don't } \\
\text { know } \\
\%\end{array}$ \\
\hline Same rights, benefits and opportunities as males & 92.2 & 3.1 & 4.7 \\
\hline Separate toilet and ablution facilities provided & 83.2 & 14.9 & 1.9 \\
\hline Equal advancement and promotion opportunities & 87.6 & 4.9 & 7.5 \\
\hline Paid same rates of pay (wages and salaries) as males & 69.2 & 7.3 & 23.4 \\
\hline $\begin{array}{l}\text { Visible management endorsement of non-discriminatory practices, } \\
\text { gender-based education programs and information }\end{array}$ & 65.2 & 18.5 & 16.3 \\
\hline Simple, clear and unambiguous communication of gender equity policy & 55.2 & 22.7 & 22.1 \\
\hline $\begin{array}{l}\text { Available funding targeted at improving status and qualifications of } \\
\text { female employees }\end{array}$ & 51.1 & 25.0 & 23.9 \\
\hline Written gender equity policy in place & 44.5 & 34.9 & 20.6 \\
\hline Provision of gender-based educational material & 27.8 & 50.0 & 22.2 \\
\hline $\begin{array}{l}\text { Practices that might be regarded as discriminatory because worker was } \\
\text { female }\end{array}$ & 8.8 & 64.3 & 26.9 \\
\hline
\end{tabular}

Table 4 Gender-based issues

Relative to observed gender-based discriminatory practices (8.8\%) respondents cited examples of these as follows, namely:

- Decision not to award a tender to a woman because of skepticism;

- Engineers undermine me and threaten to work me out;

- No ablution facilities provided on site;

- Female engineers had to be accompanied to rural sites due to danger.

Comments suggestive of prevailing attitudes towards females in construction included:

- Too many unqualified females are appointed to top positions;

- [Gender] equity is not a priority for management;

- Heavy construction work negatively affects women's reproductive organs;

- Nature of industry has not encouraged women to apply;

- Construction sites are not suited to women;

- Family responsibilities interfere with their [women's] progress;

- Fellow workers are shocked at my [woman] excellent performance.

\section{Student Survey}

While the validity of the views of students has been questioned (Ross and Elechi, 2002), their views need to be considered given that they are one of the three cooperative partners in the cooperative construction education model (Haupt, 2003). The student sample was drawn from two major universities in the Western Cape and Gauteng provinces, namely the 
University of Johannesburg (55.3\%) and the Cape Peninsula University of Technology (44.7\%). The sample was constituted as follows, namely

- Junior $\left(1^{\text {st }}\right.$ and $2^{\text {nd }}$ year) students $-43.6 \%$ (males $=31.2 \%$; females=51.2\%); and

- Senior ( $3^{\text {rd }}$ and $4^{\text {th }}$ year) students $-56.4 \%$ (males $=68.8 \%$; females $=48.8 \%$ ).

\begin{tabular}{|c|c|c|c|}
\hline Institution & $\%$ & Program & $\%$ \\
\hline CPUT & 44.7 & Construction Management & 37.5 \\
\hline UJ & 55.3 & Quantity Surveying & 60.8 \\
\hline \multirow[t]{2}{*}{ Total } & 100.0 & Civil Engineering & 1.7 \\
\hline & & Total & 100.0 \\
\hline Year /level of study & & Gender & \\
\hline Junior & 43.6 & Male & 61.0 \\
\hline Senior & 56.4 & Female & 39.0 \\
\hline Total & 100.0 & Total & 100.0 \\
\hline
\end{tabular}

Table 5 Student sample profile

From Table 5 it is evident that most (60.8\%) of the students were quantity surveying majors, $37.5 \%$ were construction management majors, and the remaining $1.7 \%$ civil engineering majors. In terms of gender, males dominated the sample.

\section{The Impact of Discrimination}

Students were presented with five statements relative to gender-based discriminatory practices in construction to which they needed to respond on a five-point scale of agreement where $1=$ totally disagree, $2=$ disagree, $3=$ neutral, $4=$ =agree and 5=totally agree. The means of their responses are presented in Table 6.

\begin{tabular}{|c|l|c|c|c|c|c|c|}
\hline \multirow{2}{*}{ Rank } & \multicolumn{1}{|c|}{ Statement } & \multicolumn{2}{|c|}{ Sample } & \multicolumn{2}{c|}{ Males } & \multicolumn{2}{c|}{ Females } \\
\cline { 3 - 7 } & Mean & SD & Mean & SD & Mean & SD \\
\hline 1 & $\begin{array}{l}\text { Women on construction sites are not } \\
\text { respected to the same extent as men }\end{array}$ & 3.5 & 1.2 & 3.2 & 1.2 & 4.0 & 0.9 \\
\hline 2 & $\begin{array}{l}\text { Women are likely to be sexually } \\
\text { harassed on site }\end{array}$ & 3.4 & 1.2 & 3.4 & 1.3 & 3.4 & 1.1 \\
\hline 3 & $\begin{array}{l}\text { The fact that there are more male } \\
\text { professionals in construction } \\
\text { intimidates women }\end{array}$ & 3.1 & 1.1 & 3.3 & 1.1 & 2.8 & 1.0 \\
\hline 4 & $\begin{array}{l}\text { Women are more suited to } \\
\text { administrative than production } \\
\text { functions on site }\end{array}$ & 2.9 & 1.3 & 3.4 & 1.2 & 2.1 & 1.1 \\
\hline 5 & $\begin{array}{l}\text { Female students are intimidated by } \\
\text { the male students in classes }\end{array}$ & 2.2 & 1.2 & 2.2 & 1.2 & 2.2 & 1.1 \\
\hline
\end{tabular}

Table 6 Discrimination against women in the construction workplace

The sample means suggest feelings of neutrality about issues of discriminatory practices except for disagreement about intimidation of female students by their male counterparts in class. Both male and female students agreed similarly that women were likely to be sexually harassed on site. They also disagreed that female students were intimidated by male students in their classes. However, female students agreed more strongly that women on construction sites were not respected to the same extent as men and were more negative about being intimidated by there being more male professionals in the industry. While males tended to agree, women tended to disagree that women were more suited to administrative 
than production functions on site. There were linear relationships between the gender of students and their responses to issues of discrimination. The Spearman's correlation coefficient of 0.353 at the 0.01 level (2-tailed) suggests that females were more likely to agree that women on construction sites were not respected to the same extent as men. Similarly, a correlation coefficient of -0.457 at the 0.01 level (2-tailed) suggests that they were more likely to disagree that women were more suited to administrative than production functions on construction sites. Further, the weak correlation coefficient of -0.188 at the 0.05 level (2-tailed) suggests that they were more likely to disagree that they were intimidated by there being more male consultants in the industry.

The Mann-Whitney tests suggested that responses were significantly gender-biased relative to women not being respected on construction sites to the same extent as men and women being more suited to administrative than site production function on construction sites. This finding was reinforced by the Kolmogorov-Smirnov test statistics. The Chi-square tests suggested that that the association was not the result of chance and that there was some association between gender and responses to issues of discrimination.

\begin{tabular}{|l|r|r|}
\hline & $\begin{array}{c}\text { Male } \\
(\%)\end{array}$ & \multicolumn{1}{|c|}{$\begin{array}{c}\text { Female } \\
\text { (\%) }\end{array}$} \\
\hline $\begin{array}{l}\text { Discrimination impacts careers in construction negatively resulting in them } \\
\text { rather choosing other careers }\end{array}$ & 49.2 & 50.8 \\
\hline Discrimination creates a sense of being inferior & 56.5 & 43.5 \\
\hline Discrimination results in less women in construction industry & 0.0 & 100.0 \\
\hline $\begin{array}{l}\text { Because of discrimination women tend to avoid construction and stick to the } \\
\text { conventional careers such as nursing }\end{array}$ & 39.3 & 60.7 \\
\hline Men think they can do all things whereas even women can do men's work & 0.0 & 100.0 \\
\hline $\begin{array}{l}\text { Most women become unsure of the available choices in the industry and end } \\
\text { up dropping out of construction }\end{array}$ & 39.3 & 60.7 \\
\hline
\end{tabular}

Table 7 Impact of discrimination against women on career choices

Table 7 shows the split by gender of responses to each of the issues about discriminatory practices in the sector. More than half of the respondents (females) reported that discrimination impacted negatively on construction career choices resulting in women choosing careers in other sectors. Further, a similar proportion of the sample (males) suggested that discrimination created among females a sense of being inferior to their male counterparts. Only females reported that discrimination resulted in less women being employed in construction and that men thought they were the only ones who could do all things. Similar proportions of the sample (females) reported that because of discrimination women tended to avoid the sector and were unsure of the career possibilities in construction.

\section{The Impact of the Low Representation of Women}

\begin{tabular}{|c|l|c|c|c|c|c|c|}
\hline \multirow{2}{*}{ Rank } & \multicolumn{1}{c|}{ Statement } & \multicolumn{2}{c|}{ Sample } & \multicolumn{2}{c|}{ Males } & \multicolumn{2}{c|}{ Females } \\
\cline { 2 - 8 } & Mean & SD & Mean & SD & Mean & SD \\
\hline 1 & $\begin{array}{l}\text { An increased number of women in } \\
\text { construction will contribute to the } \\
\text { improvement of skills shortage in the } \\
\text { construction industry }\end{array}$ & 3.5 & 1.1 & 3.3 & 1.1 & 3.8 & 0.9 \\
\hline 2 & $\begin{array}{l}\text { The low employment of women in } \\
\text { construction contributes to the skills } \\
\text { shortage in the construction industry }\end{array}$ & 3.2 & 1.2 & 3.0 & 1.2 & 3.6 & 1.1 \\
\hline
\end{tabular}

Table 8 Impact of women on skills shortages

Madikizela, K and Haupt, T (2010) 'Influences on women's choices of careers in construction: a South African study', Australasian Journal of Construction Economics and Building, 10 (1/2) 1-15 
The sample means suggest agreement about the impact of women on skills shortages. However, female students agreed more strongly that increased numbers of women would reduce the skills shortage and that the low employment levels of women in the sector actually contributed to the existence of the skills shortage. However, there was a statistically significant correlation albeit weak between gender and student responses to the impact of the low employment of women in construction to the skills shortage in the industry. The Spearman's correlation coefficient of 0.275 at the 0.01 level (2-tailed) suggests that females were more likely to agree that this was the case. Similarly, a correlation coefficient of 0.230 at the 0.05 level (2-tailed) suggests that they were more likely to agree that increased numbers of women in the industry would contribute to a reduction in the skills shortage.

\section{Relationship between Culture, Historical Background and Career Choice}

\begin{tabular}{|c|c|c|c|c|c|}
\hline Rank & Question & & $\begin{array}{l}\text { Yes } \\
(\%)\end{array}$ & $\begin{array}{l}\text { No } \\
(\%)\end{array}$ & $\begin{array}{c}\text { Unsure } \\
(\%)\end{array}$ \\
\hline \multirow{3}{*}{1} & \multirow{3}{*}{$\begin{array}{l}\text { Do you believe that cultural beliefs will } \\
\text { influence the success of your career in the } \\
\text { construction industry? }\end{array}$} & $S(N=171)$ & 20.6 & 64.0 & 14.7 \\
\hline & & $M(N=104)$ & 20.3 & 60.8 & 19.9 \\
\hline & & $\mathrm{F}(\mathrm{N}=64)$ & 19.6 & 71.7 & 8.7 \\
\hline \multirow{3}{*}{2} & \multirow{3}{*}{$\begin{array}{l}\text { Do you believe that the cultural differences } \\
\text { between males and females influence their } \\
\text { career choice? }\end{array}$} & $S(N=171)$ & 44.9 & 42.6 & 12.5 \\
\hline & & $M(N=104)$ & 50.0 & 35.1 & 14.9 \\
\hline & & $\mathrm{F}(\mathrm{N}=64)$ & 30.4 & 58.7 & 10.9 \\
\hline \multirow{3}{*}{3} & \multirow{3}{*}{$\begin{array}{l}\text { If yes, do you believe that this influence } \\
\text { contributes to the low representation of } \\
\text { women in construction }\end{array}$} & $\mathrm{S}(\mathrm{N}=89)$ & 52.3 & 31.8 & 15.9 \\
\hline & & $M(N=52)$ & 54.1 & 23.0 & 23.0 \\
\hline & & $\mathrm{F}(\mathrm{N}=37)$ & 50.0 & 40.6 & 9.4 \\
\hline \multirow{3}{*}{4} & \multirow{3}{*}{$\begin{array}{l}\text { If yes, do you believe that this contributes to } \\
\text { the prevalence of discrimination against } \\
\text { women who have entered the construction } \\
\text { industry }\end{array}$} & $\mathrm{S}(\mathrm{N}=89)$ & 45.2 & 43.3 & 10.6 \\
\hline & & $M(N=52)$ & 42.4 & 42.4 & 15.3 \\
\hline & & $\mathrm{F}(\mathrm{N}=37)$ & 48.4 & 45.2 & 6.5 \\
\hline
\end{tabular}

Table 9 Relationship between cultural beliefs, career choice and career success

From Table 9 there are no apparent significant differences between the views of males and females on the influence of culture and historical background on their potential career success. However, a greater proportion of females disagreed that cultural beliefs would influence their success (71.7\%) and that the cultural differences between the sexes would influence their choice of career $(58.7 \%)$. While, women generally tended to have more negative or positive views, there were no significant statistical correlations between gender or year of study and responses about cultural and background influences.

\section{Influences behind Career Choices}

\begin{tabular}{|l|r|r|}
\hline \multicolumn{1}{|c|}{ Students statements } & Males (\%) & Females (\%) \\
\hline Opportunities in the industry & 27.2 & 11.5 \\
\hline Looking at something I constructed makes me feel good - passion & 8.5 & 0.0 \\
\hline Fascinated by beauty of buildings & 13.6 & 8.6 \\
\hline My background and family members & 15.3 & 11.5 \\
\hline The fact that there were few women & 0.0 & 20.0 \\
\hline To challenge the perception that construction is for males & 0.0 & 22.9 \\
\hline Successful women in construction & 1.7 & 5.7 \\
\hline
\end{tabular}

Table 10 Influences behind construction career choices

Madikizela, K and Haupt, T (2010) 'Influences on women's choices of careers in construction: a South African study', Australasian Journal of Construction Economics and Building, 10 (1/2) 1-15 
Table 10 shows the relative proportions in the sample of males and females who responded to the statements on the influences behind choosing careers in construction. It is evident that males were more likely to be influenced by opportunities in the industry $(27.2 \%)$, background and family members (15.3\%), and fascination with buildings (13.6\%). On the other hand, females were more likely to be influenced by the challenge presented by the male dominant nature of the industry (22.9\%) and the paucity of women employed in the sector $(20.0 \%)$.

\begin{tabular}{|l|r|r|}
\hline \multicolumn{1}{|c|}{ Statement } & \multicolumn{1}{c|}{$\begin{array}{c}\text { Male } \\
(\%)\end{array}$} & $\begin{array}{c}\text { Female } \\
(\%)\end{array}$ \\
\hline Nothing & 30.8 & 26.7 \\
\hline Poor working conditions & 15.3 & 10.0 \\
\hline Poor safety and risk & 11.5 & 6.7 \\
\hline Money & 7.7 & 3.3 \\
\hline Discrimination against women & 0.0 & 13.3 \\
\hline Lack of understanding of career opportunities in construction & 7.7 & 6.7 \\
\hline Negative image of the construction industry & 5.7 & 26.7 \\
\hline Lack of employment in construction & 3.8 & 3.3 \\
\hline Sexual harassment done by men & 0.0 & 6.7 \\
\hline
\end{tabular}

Table 11 Influences behind not selecting careers in construction

Similarly, Table 11 shows the proportion of the sample by gender who responded to the statements on the influences for not choosing careers in construction. The findings suggest that nothing would deter both males (30.8\%) and females (26.7\%) from pursuing careers in construction if that was their choice. However, males were more likely to be deterred by poor working conditions (15.3\%) and the poor $\mathrm{H} \& \mathrm{~S}$ performance and risk management records $(11.5 \%)$ of the industry. Females were more likely to be deterred by the negative image of the industry (26.7\%), discrimination against women (13.3\%) and poor working conditions $(10.0 \%)$.

Using a three-point scale where 1= low, 2=medium and $3=$ high, students were asked to rate the influence of careers in other sectors over construction.

\begin{tabular}{|c|l|c|c|c|c|c|c|}
\hline \multirow{2}{*}{ Rank } & \multicolumn{1}{|c|}{ Influence } & \multicolumn{2}{|c|}{ Sample } & \multicolumn{2}{c|}{ Male } & \multicolumn{2}{c|}{ Female } \\
\cline { 3 - 8 } & & Mean & SD & Mean & SD & Mean & SD \\
\hline 1 & The dangerous nature of the construction work & 2.3 & 0.7 & 2.3 & 0.7 & 2.4 & 0.7 \\
\hline 2 & Challenging work environment & 2.3 & 0.7 & 2.4 & 0.7 & 2.3 & 0.8 \\
\hline 3 & $\begin{array}{l}\text { The inability to work and have influence in a } \\
\text { male dominated industry }\end{array}$ & 2.3 & 0.7 & 2.3 & 0.7 & 2.3 & 0.7 \\
\hline 4 & Male dominance of the industry & 2.3 & 0.7 & 2.3 & 0.8 & 2.2 & 0.7 \\
\hline 5 & $\begin{array}{l}\text { The seemingly discriminatory environment of } \\
\text { the construction industry }\end{array}$ & 2.2 & 0.7 & 2.2 & 0.7 & 2.3 & 0.7 \\
\hline 6 & Knowledge of the construction industry & 2.2 & 0.7 & 2.2 & 0.7 & 2.2 & 0.7 \\
\hline 7 & $\begin{array}{l}\text { The masculine and unattractive image of the } \\
\text { construction industry }\end{array}$ & 2.0 & 0.7 & 2.0 & 0.8 & 2.0 & 0.7 \\
\hline 8 & Career expectations and financial prospects & 2.0 & 0.8 & 2.1 & 0.8 & 2.0 & 0.7 \\
\hline
\end{tabular}

Table 12 Influence of career choices in other sectors over construction

The results in Table 12 suggest that the challenging work environment, dangerous nature of construction, inability to work and influence a male dominated industry, male dominance of the industry, discriminatory working environment and lack of knowledge of the industry were 
rated as being medium to high influences on other women choosing careers in other sectors instead of construction

\section{Analysis of Student Survey Findings by Year of Study}

The responses of students were further analysed to determine the impact, if any, of the year of study on their responses. However, there were no statistically significant correlations between year of study and student responses save for a weak linear negative relationship between year of study and female students being intimidated by male students in classes. In this case the Spearman's correlation coefficient of -0.241 at the 0.05 level (2-tailed) suggests that as students progressed through their studies over time females would feel less threatened by the male students in their classes.

\section{Professional Women Survey}

The professional women sample consisted of 17 construction industry professional women working in various construction industry organisations at junior, middle and senior management levels.

\section{The Impact of Discrimination}

The sample was presented with nine statements related to the impact of discrimination on their careers to which they needed to respond on a five-point scale of agreement where 1=totally disagree, $2=$ disagree, 3=neutral, 4=agree and 5=totally agree. Their responses are shown in Table 13.

\begin{tabular}{|c|c|c|c|c|c|c|c|c|c|}
\hline Rank & Statement & $N$ & $\begin{array}{c}1 \\
(\%)\end{array}$ & $\begin{array}{c}2 \\
(\%)\end{array}$ & $\begin{array}{l}3 \\
(\%)\end{array}$ & $\begin{array}{c}4 \\
(\%)\end{array}$ & $\begin{array}{c}5 \\
(\%)\end{array}$ & Mean & St Dev \\
\hline 1 & $\begin{array}{l}\text { Women experience discrimination on } \\
\text { entering the construction industry }\end{array}$ & 17 & 0.0 & 0.0 & 5.9 & 47.1 & 47.0 & 4.4 & 0.6 \\
\hline 2 & $\begin{array}{l}\text { Women who work on construction } \\
\text { sites are most likely to experience a } \\
\text { higher prevalence of discrimination } \\
\text { relative to those who work for } \\
\text { consulting firms }\end{array}$ & 17 & 0.0 & 5.9 & 17.6 & 52.9 & 23.6 & 3.9 & 1.2 \\
\hline 3 & $\begin{array}{l}\text { Women experience discrimination in } \\
\text { construction and do not experience } \\
\text { upward mobility in comparison to } \\
\text { their male counterparts }\end{array}$ & 17 & 0.0 & 23.5 & 11.8 & 47.1 & 17.6 & 3.6 & 1.1 \\
\hline 4 & $\begin{array}{l}\text { Males discriminate against pregnant } \\
\text { women in construction }\end{array}$ & 17 & 0.0 & 35.3 & 11.8 & 35.3 & 17.6 & 3.4 & 1.2 \\
\hline 5 & $\begin{array}{l}\text { My contribution as a professional } \\
\text { woman is not regarded as equally } \\
\text { important as that of my male } \\
\text { counterparts }\end{array}$ & 17 & 11.8 & 20.4 & 11.8 & 23.5 & 23.5 & 3.2 & 1.4 \\
\hline 6 & $\begin{array}{l}\text { Women who fall pregnant while } \\
\text { working in the construction industry } \\
\text { experience a higher prevalence to } \\
\text { discrimination than those on other } \\
\text { sectors }\end{array}$ & 17 & 0.0 & 11.8 & 23.5 & 35.3 & 17.4 & 3.1 & 1.3 \\
\hline 7 & $\begin{array}{l}\text { Women working in construction do } \\
\text { not have the same opportunities to } \\
\text { develop as their male colleagues }\end{array}$ & 17 & 0.0 & 29.2 & 23.5 & 23.5 & 11.8 & 2.9 & 1.2 \\
\hline 8 & $\begin{array}{l}\text { I have experienced discrimination in } \\
\text { my workplace }\end{array}$ & 17 & 5.9 & 17.6 & 23.5 & 35.3 & 17.7 & 2.9 & 1.2 \\
\hline 9 & $\begin{array}{l}\text { The nature of the construction } \\
\text { industry poses a threat to the career } \\
\text { development of women in } \\
\text { construction }\end{array}$ & 17 & 0.0 & 41.2 & 17.6 & 11.8 & 29.4 & 2.1 & 0.9 \\
\hline
\end{tabular}

Table 13 Discrimination against women in the construction workplace

Madikizela, K and Haupt, T (2010) 'Influences on women's choices of careers in construction: a South African study', Australasian Journal of Construction Economics and Building, 10 (1/2) 1-15 
From Table 13, almost all the women (94.1\%) believed that women experienced discrimination while working in the construction industry. About three-quarters $(76.5 \%)$ believed that this discrimination was more prevalent on construction sites than in consultancies. Furthermore, $64.7 \%$ agreed that women in construction did not enjoy the same opportunities for upward mobility as their male counterparts. More than half $(52.7 \%)$ believed that pregnant women experienced discrimination which was more prevalent in construction than in other sectors. More than half $(53.0 \%)$ of the respondents had experienced discrimination at work. Almost half (47\%) reported that their contribution as professional women was not regarded as equally important to that of their male counterparts. Further, $41.2 \%$ believed that the nature of the construction industry posed a threat to the career development of women in the sector.

\section{The Impact of Low Representation of Women}

The responses to two questions related to the impact of the low representation of women on the skills shortage experienced by the construction sector are shown in Table 14.

\begin{tabular}{|c|l|c|c|c|c|c|c|}
\hline Rank & \multicolumn{1}{|c|}{ Question } & N & $\begin{array}{c}\text { Yes } \\
(\%)\end{array}$ & $\begin{array}{c}\text { No } \\
(\%)\end{array}$ & $\begin{array}{c}\text { Unsure } \\
(\%)\end{array}$ & Mean & SD \\
\hline 1 & $\begin{array}{l}\text { Do you believe that the Employment Equity Act } \\
\text { is addressing the skills shortage in construction? }\end{array}$ & 17 & 50.0 & 14.3 & 35.7 & 1.9 & 0.9 \\
\hline 2 & $\begin{array}{l}\text { Do you believe that the low number of women } \\
\text { choosing careers in construction contributes to } \\
\text { the skills shortage? }\end{array}$ & 17 & 80.0 & 20.0 & 0.0 & 1.2 & 0.4 \\
\hline
\end{tabular}

Table 14 Impact of women on skills shortages

Half (50.0\%) of the women believed that the Employment Equity Act was addressing the low representation of women in construction and subsequently the skills shortage in the industry. However, most (80.0\%) of them held that despite this legislation low numbers of women in the construction industry exacerbated the skills shortage.

\section{Influence of Culture, Nature of Industry and Career Choice}

Participants in the study were presented with three statements on the influence of culture and the nature of the industry on the career choices of women. Their responses are shown in Table 15.

\begin{tabular}{|c|l|c|c|c|c|c|c|c|c|}
\hline Rank & \multicolumn{1}{c|}{ Statement } & $\mathbf{N}$ & $\begin{array}{c}\mathbf{1} \\
(\%)\end{array}$ & $\begin{array}{c}\mathbf{2} \\
(\%)\end{array}$ & $\begin{array}{c}\mathbf{3} \\
(\%)\end{array}$ & $\begin{array}{c}\mathbf{4} \\
(\%)\end{array}$ & $\begin{array}{c}\mathbf{5} \\
(\%)\end{array}$ & Mean & $\begin{array}{c}\text { St } \\
\text { Dev }\end{array}$ \\
\hline 1 & & & & & & & & \\
\hline & $\begin{array}{l}\text { I would encourage other young women } \\
\text { to pursue a career in construction, } \\
\text { because I believe that there is a place } \\
\text { and a need for females in the industry }\end{array}$ & 17 & 0.0 & 0.0 & 0.0 & 29.4 & 70.6 & 4.7 & 0.5 \\
\hline 2 & $\begin{array}{l}\text { Women's cultural beliefs and } \\
\text { background influence their success in } \\
\text { the construction industry }\end{array}$ & 17 & 5.9 & 23.5 & 29.4 & 11.9 & 29.3 & 3.3 & 1.3 \\
\hline $\begin{array}{l}\text { My experience within the construction } \\
\text { industry confirmed my expectations and } \\
\text { beliefs of the industry being male } \\
\text { dominated and discriminatory towards } \\
\text { women }\end{array}$ & 17 & 0.0 & 35.4 & 23.5 & 35.5 & 5.9 & 3.1 & 0.9 \\
\hline
\end{tabular}

Table 15 Cultural beliefs, industry nature and career success

Professional women strongly agreed (mean=4.7) that they would encourage women to consider careers in construction, as there was a need for more women in construction. However, they were somewhat neutral (mean=3.3) about the influence of their cultural beliefs and background on their prospects of successful careers in the sector. They were 
somewhat surprisingly neutral (mean=3.1) about whether their experience in the industry had confirmed their views about the industry being both male dominant and discriminatory towards women. It is possible that as they gained experience and acceptance in the industry over time that they became less sensitive to the male dominance and discrimination.

\section{Influences behind Career Choices}

It is evident that job opportunities in the South African construction sector driven by government initiatives, women's desire to demonstrate their ability to compete equally with men in a male dominated industry, availability of bursaries, influence of family and opportunities for financial independence all influence women when choosing careers in construction.

Comments by women included, inter alia:

- I wanted to prove that women are strong and are capable of handling the harsh realities of construction activities;

- The fact that women are taken as powerless and unable to do what men can do. I want to be independent as an African woman who can do things without having to depend on male counterparts;

- I was attracted by non-formal clothing, the fact that work on site was not officebased, and jobs are constantly changing.

\section{Student Views Compared with Professional Women Views}

The findings suggest that experience of the industry by professional women tempered their views relative to the industry itself when compared with the responses of students. The findings suggest that there might be a relationship between the perceptions held by the female students about their success in construction and their experience of the sector. The responses of the professional women working in the construction industry suggest that this prospect is likely. Similarly, the experience of women in the industry suggested that as they gained more experience and acceptance in the industry they were able to hold their own and develop more realistic views of the nature of the sector.

\section{Discussion}

Despite government efforts to increase the participation ratio of women in construction, bodies such as the South African Women in Construction (SAWiC) and Construction Industry Development Board suggest that while there have been increases these have been

\begin{tabular}{|c|c|c|c|c|}
\hline $\begin{array}{c}\text { Contractor } \\
\text { Grading } \\
\text { Designation }\end{array}$ & $\begin{array}{c}\text { Maximum Value of } \\
\text { Contract }\end{array}$ & Total & Women owned & \% of Total \\
\hline 1 & R200,000 & 67,119 & 32,593 & 49 \\
\hline 2 & R500,000 & 4,735 & 2,206 & 47 \\
\hline 3 & R1,500,000 & 1,271 & 600 & 47 \\
\hline 4 & R3,000,000 & 1,718 & 692 & 40 \\
\hline 5 & R5,000,000 & 1,096 & 407 & 37 \\
\hline 6 & R10,000,000 & 877 & 274 & 31 \\
\hline 7 & R30,000,000 & 435 & 94 & 8 \\
\hline 8 & R100,000,000 & 121 & 10 & 1 \\
\hline 9 & No limit & 119 & 1 & 48 \\
\hline
\end{tabular}

Table 16 CIDB Contractor gradings and breakdown of registered contractors (Source: www.cidb.org accessed April 3, 2009) 
marginal and at the lowest end of the CIDB contractor grades. Table 16 shows the respective CIDB contractor grades.

The CIDB register of contractors has 77,491 construction enterprises of which $48 \%$ are owned by women, namely 36,877 . However, $88.4 \%$ of these enterprises fall within the lowest category of registration, namely grade one. A further $7.6 \%$ are in grades two and three. Only $4 \%$ are registered in grades four and higher. Only ten contractors are registered at grade 8. It is likely that the low numbers of qualified women entering the industry contributes to the lack of women-owned contracting firms the higher grades of the CIDB register.

The survey of industry stakeholders confirmed that most construction firms employed small numbers of women per annum in their organisations. These women were mostly employed to perform secretarial and administrative roles. Where they were employed on construction sites they were typically employed at the level of laborers suggesting that women were regarded to be more suited to administrative than production functions on site. Female students in particular opined that women on construction sites were not respected to the same extent as men and were intimidated by there being more male professionals in the industry. There is evidently a need for women to review their own professional roles and accept themselves as competent professional women in their own right.

Almost all respondents reported that females were afforded the same rights, benefits and opportunities as males in their organisations, had separate facilities such as toilets and ablutions and were afforded equal advancement and promotion opportunities. However, substantially less reported that there was available funding targeted at improving the status and qualifications of female employees, written gender equity policies in place, and genderbased educational material provided. These findings suggest a lack of visible and tangible commitment to empower women in their organisations.

Perceived or real discriminatory practices impacted negatively on career choices by women in construction. Arguably, if jobs or work climate were developed to provide a more desirable work environment devoid of overt and covert sexism and racism and inflexible working structures an increase in the numbers of women attracted to work in construction would likely result. The current situation results in large reserves of skill and talent remaining untapped. The study found that increasing the numbers of women in the sector would reduce the skills shortage and that the low employment levels of women in the sector actually contributed to the existence of the skills shortage. However, Dainty et al. (2004) suggest that women have a poor initial understanding of the culture of the industry and the inherent difficulties of working in a male-dominated and oriented environment. The findings of the study supported the view that there was a general lack of knowledge by women of the industry itself and the career opportunities it offered, suggesting that there might be a relationship between knowledge of the construction industry and the choice of careers in construction.

The study found no significant differences between the views of males and females on the influence of culture and historical background on their career success. Furthermore, contrary to common belief, cultural beliefs and backgrounds were not major influences on career choices made by women. However, females agreed more strongly that neither cultural beliefs nor the cultural differences between the sexes would influence their choice of career or their success. Given the challenging work environment, dangerous nature of construction, inability to work in or influence a male dominated industry, male dominance of the industry, discriminatory working environment and lack of knowledge of the industry women were more likely to choose careers in other sectors instead of construction.

Women tended to believe that legislation such as the Employment Equity Act created the platform for the low representation of women in construction to be addressed. However, 
most of them held that despite this legislation there continued to be low numbers of women in the construction industry that exacerbated the skills shortage. Evidently, more than just legislation is needed.

The study findings suggest that it is possible that as they gained experience and acceptance in the industry over time women became less sensitive to the male dominance and discrimination. The study also found that women in construction did not enjoy the same opportunities for upward mobility as their male counterparts. Pregnant women experienced discrimination which was more prevalent in construction than in other sectors and many women had themselves experienced discrimination at work. The contribution of women as professionals was not regarded as important as that of their male counterparts. Clearly, the current nature of the construction industry posed a threat for the career development of women in the sector.

\section{Conclusion}

The findings of this study confirm the gender bias that still exists within the South African construction sector. The male dominant nature of the industry and gender-based discrimination experienced by women employed in the industry are challenges that need to be overcome if increasing numbers of women are to choose careers in construction. Legislation by itself is insufficient to boost the present low numbers of women and significantly reduce the skills shortage in the industry. The overall poor image of the industry presents a further inhibitive factor to women choosing to work in construction. The industry needs to make a more visible and tangible commitment to empowering women at all levels by providing equal opportunities for women. Gender relations need to change. Access to construction education needs to be widened and the specific barriers, image and culture addressed. However, it is also necessary for women to review their own roles and accept themselves as competent contributors to the industry in their own right.

\section{References}

Agapiou, A. (2002) 'Exploring the attitudes of school-age children, their parents and educators to career prospects in the Scottish construction industry', Equal Opportunities International, 12(8), 18-29

Bennett, J., Davidson, M. and Gale, A. (1999) 'Women in construction: a comparative investigation into the expectations and experiences of female and male construction undergraduates and employees', Women in Management Review, 14 (7), 273-292

Dainty, A., Bagilhold, B., Ansari, K., and Jackson, J. (2004) 'Creating equality in the construction industry: An agenda for change for women and ethnic minorities', Journal of Construction Research, 5 (1), 75-86

Ellison, L. (2001) 'Senior management in chartered surveying: where are the women?' Women in Management Review, 16 (6), 264 -278

Fielden, SL., Davidson, M. J., Gale, A. and Davey, C. L. (2001) 'Women, equality and construction', The Journal of Management Development, 20 (4), 293 - 305

Gale, A. (1994) 'Women in non- traditional occupations: The construction industry', Women in Management Review, 9 (2), 3-14

Greed, C. (2006) 'Social exclusion: Women in construction', in Managing Diversity and Equality in Construction: Initiatives and Practice, eds A. W. Gale, \& M. Davidson, Taylor \& Francis, London, 71-97

Guppy, A. and Rick, J. (1996) 'The influence of gender and grade on perceived work stress and job satisfaction in white collar employees', Work and Stress, 10 (2), 154-164

Haupt, TC. (2003) 'Student attitudes towards co-operative construction education experiences', Australian Journal of Construction Economics and Building, 3 (1), 29-40 
Haupt, T. and Smallwood, J. (2004) 'Gender equity in construction: myth or reality?' Contact Africa, 3 (2), 4

International Labor Organization, (2008) Global Employment Trends for Women - March 2008, International Labor Organization, Geneva

Johnson, D. (1999) Transforming organizations: management cultures, women and leadership in South Africa, unpublished

Kloot, L. (2004) 'Women and leadership in universities: a case study of women academic managers', The International Journal of Public Sector Management, 17 (6), 470-485

Kornegay, E. (2000) South African National Framework for Women's Empowerment and Gender Equality, The Office on the Status of Women

Mathur-Helm, B. (2005) 'Equal opportunity and affirmative action for South African women: a benefit of barrier?' Women in Management Review, 20 (1), 56-71

Mathur-Helm, B. (2004) 'Women in management in South Africa', in Women in Management Worldwide: Progress and Prospects, eds L. Davidson and R. Burke Ashgate Publishing Company, Aldershot

National Gender Policy Framework, (2003) Women's Empowerment and Gender Equality, National Gender Policy Framework, Pretoria

Phaahla, P. (2000) 'Bridging the gender divide in South African higher education management and leadership', Paper presented at the 13th Annual International Conference on Women in Higher Education, 8-12 January, New Orleans, Louisiana, 1-10

Ross, L.E. and Elechi, OO. (2002) 'Student attitudes towards internship experiences: From theory to practice', Journal of Criminal Justice Education, 13 (2), 297-312

Sachs, R., Chrisler, J. and Devlin, A. (1992) 'Biographic and personal characteristics of women in management', Journal of Vocational Behaviour, 13, 439-447

Schein, VE. (1978) 'Sex role stereotyping, ability and performance: Prior research and new directions', Personnel Psychology, 31, 259-268

Thompson, N. (1997) 'Women in construction', WiseNet, 43, (7 pages) www.wisenetaustralia.org

The Republic of South Africa, (1996) Constitution of The Republic of South Africa, Act No.108 of 1996, Government Printers, Pretoria

The Republic of South Africa, (1998) The Employment Equity Act No 55 of 1998, Government Printers, Pretoria

Wilson, E. M. (1998) 'Gendered career paths', Personnel Review, 27 (5), 398 - 411 